\title{
The Economics and Productivity of Organic versus Conventional U.S. Dairy Farms
}

\author{
Richard F. Nehring*(1), Jeffrey Gillespie, Catherine Greene and Jonathan Law \\ USDA - Economic Research Service, Washington, DC, USA \\ ${ }^{\star}$ Corresponding author. Email: richard.nehring@usda.gov
}

\begin{abstract}
United States certified organic and conventional dairy farms are compared on the basis of economic, financial, and technological measures using dairy data from the 2016 USDA Agricultural Resource Management Survey. A stochastic production frontier model using an input distance function framework is estimated for U.S. dairy farms to examine technical efficiency and returns to scale (RTS) of farms of both systems and by multiple size categories. Financial and economic measures such as net return on assets and input costs, as well as technological adoption measures are compared by system and size. For both systems, size is the major determinant of competitiveness based on selected measures of productivity and RTS.
\end{abstract}

Keywords: Milk; cows; organic; conventional; stochastic production frontier; US dairy

JEL Classifications: Q12; Q14; Q18

\section{Introduction}

Over the past 20 years, USDA certified organic milk production (referred to as simply "organic milk production" for purposes of this paper) has continued to expand so that it now claims a consequential share of U.S. milk production. Estimates from the 2005, 2010, and 2016 U.S. Agricultural Resource Management Surveys (ARMS), dairy versions, show that organic milk production represented $0.7 \%, 4.1 \%$, and $6.6 \%$ of total U.S. milk production in those years, respectively. ${ }^{1}$ Production expansion has occurred alongside increased demand for USDA certified organic milk, driven by consumer concerns for animal welfare, the environment, and human health (Greene and McBride, 2015). Along with the expansion in production, organic dairy farming has evolved such that it differs dramatically by size (McBride and Greene, 2009), leading to questions about the competitiveness of organic milk production by operation size.

Using ARMS data, we explore the extent of U.S. organic milk production in 2016, estimate returns to scale (RTS) and technical efficiency (TE) associated with organic versus conventional production by size and system, and compare financial performance of organic with conventional farms in various size categories. We estimate economic performance measures by dairy production system (organic versus conventional) using a stochastic production frontier (SPF) approach. We follow Morrison-Paul et al. (2004a) and Morrison-Paul, Nehring, and Banker (2004b) using

Data from the 2016 USDA Agricultural Resource Management Survey.

${ }^{1}$ The expanded summary of the Dairy ARMS data provides a reasonable estimate of the dairy cow population. The summary total closely approximates totals in the 2017 Census data. ARMS dairy costs and returns data show 8,982,754 cows, which is close to the 2017 Census number of 9,538,631. The 411 organic dairy observations represent $5.1 \%$ of cows, down slightly from the 5.7\% figure reported in Nehring, Barton, and Hallahan (2017) using 2010 dairy ARMS data.

(C) United States Department of Agriculture 2021. To the extent this is a work of the US Government, it is not subject to copyright protection within the United States. Published by Cambridge University Press. This is an Open Access article, distributed under the terms of the Creative Commons Attribution licence (http://creativecommons.org/licenses/by/4.0/), which permits unrestricted re-use, distribution, and reproduction in any medium, provided the original work is properly cited. 


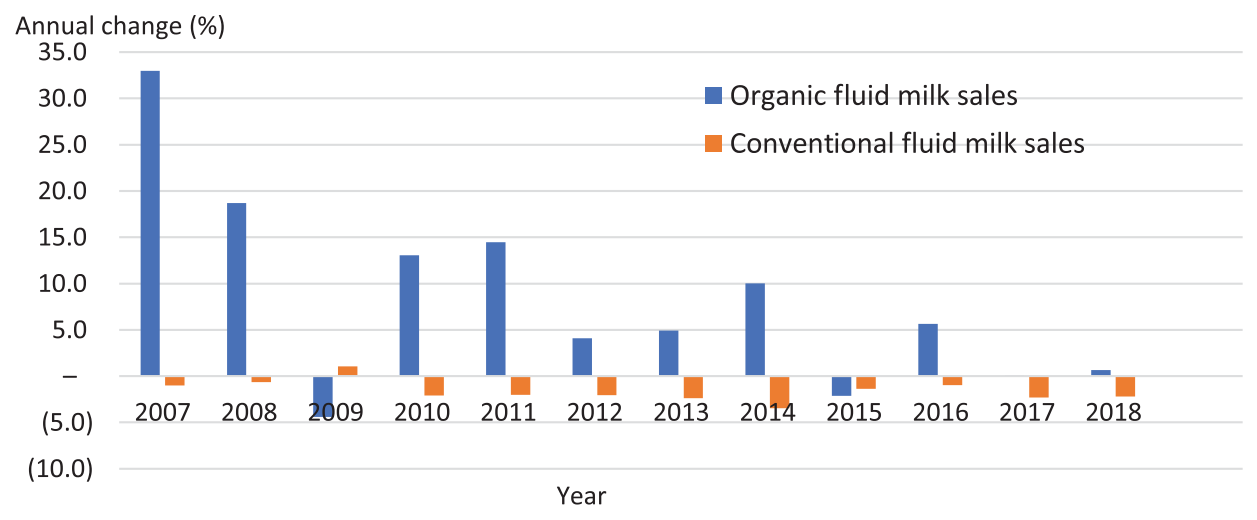

Figure 1. U.S. organic and conventional fluid milk sales, annual change, 2007-2018.

Source: USDA-ERS based on data from USDA Agricultural Marketing Service, Federal Milk Marketing.

an input distance function specification to analyze economic performance by group. We find that large farms economically outperform smaller farms in both organic and conventional categories. We highlight financial, economic, and technical differences across organic dairies compared to conventional dairies by size, providing additional perspective to the McBride and Greene (2009) and Nehring, Barton, and Hallahan (2017) results.

\subsection{Emergence of the U.S. Certified Organic Dairy Sector}

In the U.S., an organic dairy sector began emerging in the 1990s and has continued to expand over time. The sector, which included only about 2,000 certified organic dairy cows nationwide in the early 1990s, had expanded to over 40,000 cows by 2001 (Greene, 2001; Greene and Kremen, 2003). According to data from USDA's most recent national organic producer survey, over 2,500 organic dairy farmers managed a peak inventory of nearly 300,000 certified organic milk cows in 2016, accounting for $3 \%$ of the total U.S. dairy herd. Organic milk production in the European Union has shown a similar growth pattern (Willer and Lernaud, 2019).

The U.S. has had several business models for organic dairy production and processing since the early 1990s. Most U.S. organic dairy farms are small-scale family farms and many belong to Organic Valley, a farmer-owned cooperative that sets member-determined pay prices for milk and provides equity ownership in its national brand. The U.S. also has several large-scale corporate organic dairy processors (Greene and McBride, 2015). Despite the overall expansion of the organic dairy sector, the U.S. average number of milk cows per organic dairy farm has remained relatively flat, averaging 115 and 109 milk cows per farm in 2011 and 2016, respectively. The challenges involved in meeting USDA's pasture standard for organic dairy farms, implemented in 2011, may have dampened the movement to large-scale organic dairy farms that has been seen in conventional dairy production. This standard requires that cows receive $\geq 30 \%$ of their dry matter intake from pasture grazed during a grazing season of $\geq 120$ days, depending upon the region.

According to USDA estimates, overall U.S. consumption of milk, yogurt, butter, cheese, and other dairy products fell from 339 pounds per person in 1970 to 276 pounds in 2012, and cheese has replaced milk as the top dairy product consumed. The decline in recent years has been due to lower fluid milk product sales, which showed negative annual growth for conventional milk for most years between 2007 and 2018. In contrast, organic fluid milk product sales nearly doubled during that period, and the organic market share of total U.S. fluid milk sales has increased steadily, from $1.9 \%$ in 2007 to nearly 5.5\% in 2018. See Figure 1 for an illustration of changes in conventional and organic fluid milk sales from 2007 to 2018.

Organic dairy products are the second-leading food category-after fresh fruit and vegetables-for U.S. retail sales of organic food. In the U.S., food producers can label their 
products as organic only if they meet USDA's comprehensive regulatory standards for environmental stewardship, including prohibitions on the use of antibiotics, hormones, and most pesticides in crop and pasture production. USDA-ERS analysis of U.S. organic sales data for five major retail food categories shows that the organic market share increased for most categories between 2009 and 2014. The highest organic market share in 2014 was for organic milk (14\% of total sales), up from 11\% in 2009 (Greene et al., 2017). However, USDA estimates of total fluid milk sales show a flattening of sales growth at the farm level between 2014 and 2018.

A number of studies have compared characteristics of organic with conventional milk production. They have compared farm size and production practices (Zwald et al., 2004), production efficiency (Reksen, Tverdal, and Ropstad, 2005), and risk (Hanson et al., 2004). Few have compared the economics of organic with conventional milk production, with most conducted outside the U.S. (Rosati and Aumaitre, 2004). In the U.S., Butler (2002) compared net returns of California organic and conventional milk production. Dalton et al. (2005) examined net returns associated with Maine and Vermont organic dairies. Both studies showed higher revenue per cow with organic relative to conventional production, but no economic profit.

Three studies used 2005 ARMS data to analyze organic dairy economics. Estimating a cost function, Mayen, Balagtas, and Alexander (2009) found economies of scope in organic milk production, but not in conventional production. Mayen, Balagtas, and Alexander (2010) examined TE and self-selection into organic production, estimating a Cobb-Douglas SPF. Our work builds on theirs in important ways: we analyze TE using a translog input distance function in a wholefarm context and we use 2016 ARMS dairy data. McBride and Greene (2009) showed higher production costs for organic dairies, although the additional production costs were lower for pasturebased than non-pasture-based operations. They did not estimate TE and RTS components of organic relative to conventional production.

\section{Data and Methods}

Data from the 2016 ARMS Phase 3, dairy version, conducted by USDA-National Agricultural Statistics Service and Economic Research Service, are used for this study. ARMS is an annual survey of all types of farms in the 48 contiguous U.S. states. In addition to questionnaire versions directed to all types of farms, the survey also includes questionnaire versions directed to producers of 2-3 specific target commodities, with target commodities rotated each year.

The survey targeted dairy producers with a specific questionnaire version in 2016, following earlier dairy versions in 2000, 2005, and 2010. The sample for commodity versions is designed to include commercial producers of the commodity in states accounting for at least $90 \%$ of national production. For the dairy version, commercial producers are defined as operations with at least 10 milk cows, and in 2016, the dairy data set included 1,526 usable responses, including 411 organic dairies. The ARMS collects information on farm size and type, income and expenses, farm and household characteristics, and production practices. Commodity versions add commodityspecific questions on expenses, gross returns, production, and production practices.

The ARMS is a design-based survey that uses stratified sampling, so weights or expansion factors are included for each observation, allowing for the extension of results to the dairy farm population of the largest dairy states in the U.S. Regions and states included in the dairy version include the East (Maine, New York, Pennsylvania, Vermont, and Virginia), South (Florida, Georgia, Kentucky, Texas, and Tennessee), Heartland (Illinois, Iowa, Indiana, Kansas, Michigan, Minnesota, Missouri, Ohio, South Dakota, and Wisconsin), Mountain (Arizona, Colorado, and Utah), and West (California, Oregon, and Washington). Figure 2 shows relative percentages of organic operations by region for 2005, 2010, and 2016, note increases in the percentages in all regions except for the South and Mountain regions. 


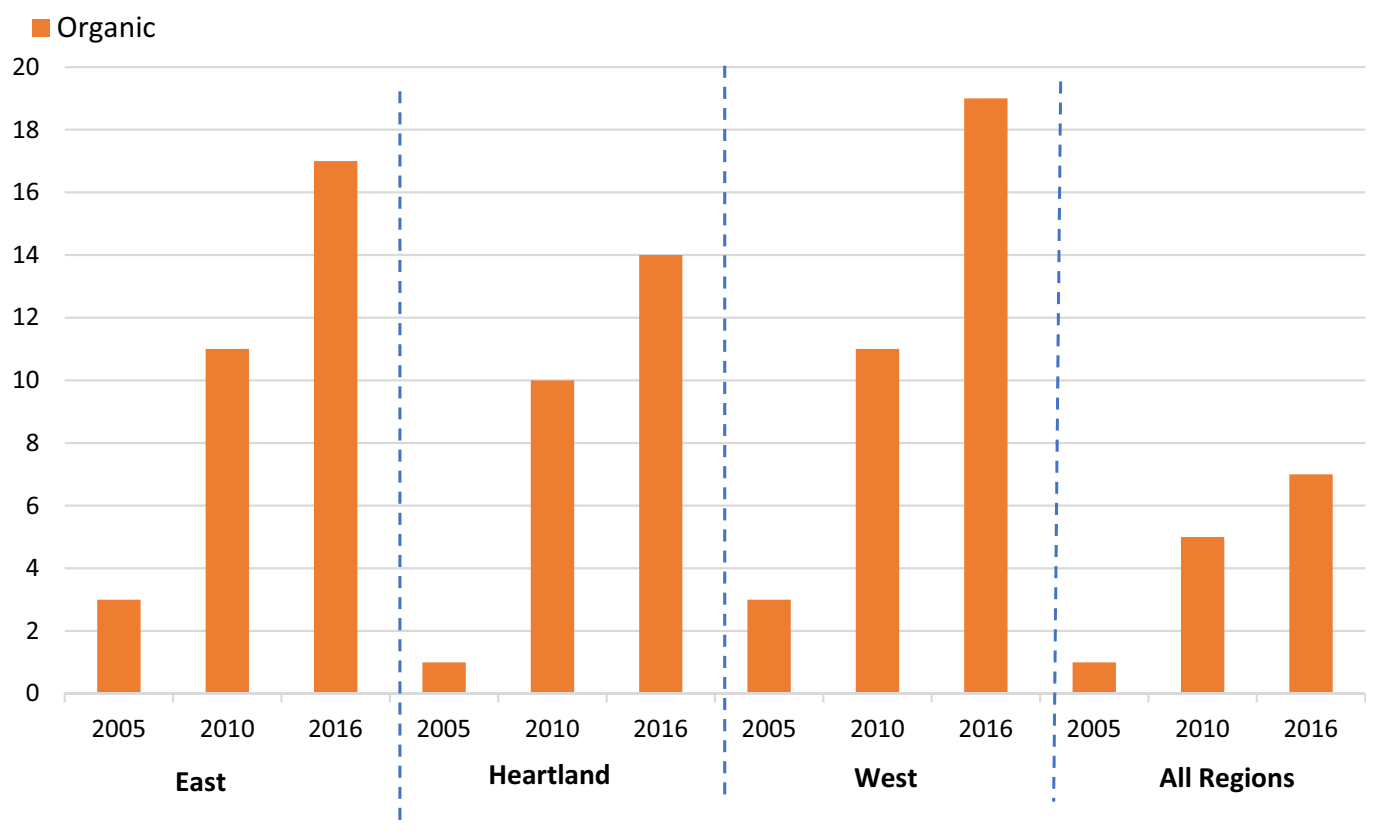

Figure 2. Percent of dairy farms with organic dairy operations by region. Source: 2016 ARMS Phase 3, Dairy Version.

\subsection{Characterizing Dairy Farm Production Technology}

A parametric input distance function approach is used to characterize the production technology of U.S. dairy farms. The input distance function is denoted as $D^{I}(\boldsymbol{X}, \boldsymbol{Y}, \boldsymbol{R})$, with $\boldsymbol{X}$ referring to inputs, $\boldsymbol{Y}$ to outputs, and $\boldsymbol{R}$ to other farm efficiency determinants. Two outputs are included in our model for dairy farms: $Y_{D A I R}=$ value of dairy production and $Y_{O T H}=$ value of production of all other crops and livestock on the farm. Inputs include expenses associated with: $X_{L A B}=$ labor; $X_{C A P}=$ capital; and $X_{M I S C}=$ miscellaneous including fuel, fertilizer, and feed. In addition, $X_{L A N D}=$ land, where differences in land characteristics are accounted for by starting with state-level quality-adjusted values for the U.S. as estimated in Ball et al. (2008), and multiplying these by pasture and non-pasture acres to construct a stock of land by farm. A service flow for land is computed based on a service life of 20 years and interest rate of $6 \%$, as discussed by Nehring et al. (2006). Ignoring land heterogeneity, urbanization effects, and climatic information would result in biased efficiency estimates (Ball et al., 2008; Nehring et al., 2006). ${ }^{2}$ All inputs included in the input distance function, including expenses and land, are for the whole-farm.

Estimation of $D^{I}(\boldsymbol{X}, \boldsymbol{Y}, \boldsymbol{R})$ requires the imposition of linear homogeneity in input levels (Färe and Primont, 1995), accomplished through normalization (Lovell et al., 1994): $D^{I}(\boldsymbol{X}, \boldsymbol{Y}, \boldsymbol{R}) / X_{1}=D^{I}\left(\boldsymbol{X} / \boldsymbol{X}_{1}, \boldsymbol{Y}, \boldsymbol{R}\right)=D^{I}\left(\boldsymbol{X}^{\star}, \boldsymbol{Y}, \boldsymbol{R}\right)$. Approximation using a translog functional form results in the following specification:

$$
\begin{aligned}
\ln \mathrm{D}_{\mathrm{it}}^{\mathrm{I}} / X_{1, \mathrm{it}}= & \alpha_{0}+\Sigma_{\mathrm{m}} \alpha_{\mathrm{m}} \ln X_{\mathrm{mit}}^{*}+.5 \Sigma_{\mathrm{m}} \Sigma_{\mathrm{n}} \alpha_{\mathrm{mn}} \ln X_{\mathrm{mit}}^{*} \ln X_{\mathrm{nit}}^{*}+\Sigma_{\mathrm{k}} \beta_{\mathrm{k}} \ln Y_{\mathrm{kit}} \\
& +.5 \Sigma_{\mathrm{k}} \Sigma_{1} \beta_{\mathrm{kl}} \ln Y_{\mathrm{kit}} \ln Y_{\mathrm{lit}}+\Sigma_{\mathrm{q}} \phi_{\mathrm{q}} R_{\mathrm{qit}}+.5 \Sigma_{\mathrm{q}} \Sigma_{\mathrm{r}} \phi_{\mathrm{qr}} R_{\mathrm{qit}} R_{\mathrm{rit}} \\
& +\Sigma_{\mathrm{k}} \Sigma_{\mathrm{m}} \gamma_{\mathrm{km}} \ln Y_{\mathrm{kit}} \ln X_{\mathrm{mit}}^{*}+\Sigma_{\mathrm{q}} \Sigma_{\mathrm{m}} \gamma_{\mathrm{qm}} \ln R_{\mathrm{qit}} \ln X_{\mathrm{mit}}^{*} \\
& +\Sigma_{\mathrm{k}} \Sigma_{\mathrm{q}} \gamma_{\mathrm{kq}} \ln Y_{\mathrm{kit}} \ln R_{\mathrm{qit}}+\mathrm{v}_{\mathrm{it}}=\mathrm{TL}\left(X^{*}, Y, R\right)+\mathrm{v}_{\mathrm{it}}, \text { or }
\end{aligned}
$$

\footnotetext{
${ }^{2}$ For further information on handling the land heterogeneity problem in SPF estimation, see Nehring et al. (2018) where characteristics affecting land quality are discussed in developing the quality-adjusted land estimate.
} 


$$
-\ln X_{1, i t}=\mathrm{TL}\left(\boldsymbol{X}^{*}, \boldsymbol{Y}, \boldsymbol{R}\right)+\mathrm{v}_{\mathrm{it}}-\ln \mathrm{D}_{\mathrm{it}}^{\mathrm{I}}=\mathrm{TL}\left(\boldsymbol{X}^{*}, \boldsymbol{Y}, \boldsymbol{R}\right)+\mathrm{v}_{\mathrm{it}}-\mathrm{u}_{\mathrm{it}},
$$

where $i$ denotes farm; $t$ the time period; $k, l$ the outputs; $m, n$ the inputs; and $q, r$ the $\boldsymbol{R}$ variables. In our analysis, $X_{1}$ is land, so the function is specified on a per-acre basis. Structural $\boldsymbol{R}$ variables include soil texture (TEXT), water-holding capacity of the soil (WATHCA), the population accessibility of the farm to urban areas (URBAN), and whether the farm is certified organic (ORGANIC). TL(.) refers to the translog SPF. Stochastic frontier production methods used to estimate this equation were first developed by Aigner, Lovell, and Schmidt (1977) and Meeusen and van den Broeck (1977). Distance from the frontier $-\ln \mathrm{D}_{\text {it }}^{\mathrm{I}}$ is measured as a technical inefficiency error $-u_{i t}$. This error is combined with a random error component $\nu_{i t}$, which represents factors such as measurement error and unobserved inputs that generate noise in the data. The $\nu_{i t}$ is assumed to be an independently and identically distributed random variable, $\mathrm{N}\left(0, \sigma_{\mathrm{v}}{ }^{2}\right)$. The $-\mathrm{u}_{\mathrm{it}}$ is assumed to be non-negative, independently distributed with truncation at zero with distribution $\mathrm{N}\left(\mathrm{m}_{\mathrm{it}}, \sigma_{\mathrm{u}}^{2}\right)$, where $\mathrm{m}_{\mathrm{it}}=\mathrm{R}_{\mathrm{it}}$.

The marginal productive contributions (MPC) of outputs and inputs are estimated by the firstorder elasticities, $\mathrm{MPC}_{\mathrm{m}}=-\varepsilon_{\mathrm{DI}, \mathrm{Ym}}=-\partial \ln \mathrm{D}^{\mathrm{I}}(\boldsymbol{X}, \boldsymbol{Y}, \boldsymbol{R}) / \partial \ln Y_{\mathrm{m}}=\varepsilon_{\mathrm{X} 1, \mathrm{Ym}}$ and $\mathrm{MPC}_{\mathrm{k}}=-\varepsilon_{\mathrm{DI}, \mathrm{X}^{*} \mathrm{~m}}=$ $-\partial \ln \mathrm{D}^{\mathrm{I}}(\boldsymbol{X}, \boldsymbol{Y}, \boldsymbol{R}) / \partial \ln X^{\star}{ }_{\mathrm{k}}=\varepsilon_{\mathrm{X} 1, \mathrm{X}{ }^{*} \mathrm{k}}$. The increase in overall input use when output expands is represented by $\mathrm{MPC}_{\mathrm{m}}$ and is expected to be positive, such as an output elasticity or marginal cost measure. The shadow value of the $\mathrm{k}^{\text {th }}$ input relative to $X_{1}$ is represented by $\mathrm{MPC}_{\mathrm{k}}$ (Fare and Primont, 1995) and, like the slope of an isoquant, is expected to be negative. MPCs of structural factors are measured through elasticities $\mathrm{MPC}_{\mathrm{Rq}}=-\varepsilon_{\mathrm{DI}, \mathrm{Rq}}=-\partial \ln \mathrm{D}^{\mathrm{I}}(\boldsymbol{X}, \boldsymbol{Y}, \boldsymbol{R}) / \partial R_{\mathrm{q}}=\varepsilon_{\mathrm{X} 1, \mathrm{Rq}}$. The total contribution of the M outputs $Y_{\mathrm{m}}$, or the scale elasticity $\mathrm{SE}=-\varepsilon_{\mathrm{DI}, \mathrm{Y}}=-\Sigma_{\mathrm{m}} \partial \ln \mathrm{D}^{\mathrm{I}}(\boldsymbol{X}, \boldsymbol{Y}, \boldsymbol{R}) /$ $\partial \ln Y_{\mathrm{m}}=\varepsilon_{\mathrm{X} 1, \mathrm{Y}}$, provides a measure of scale economies (SE). Increasing RTS is found if $\mathrm{SE}<1$. We estimate TE “scores” as TE $=\exp \left(-\mathrm{u}_{\mathrm{it}}\right)$.

\subsection{Selection Bias}

Bias associated with selecting organic versus conventional production may be of concern for SPF estimation. Because organic producers self-select into organic production, their productivity may have been higher or lower than that of conventional farmers regardless of whether or not they had chosen to produce organic milk. In past studies, selection bias in organic dairy farming has been corrected for using propensity score matching (Mayen, Balagtas, and Alexander, 2010) and by including an inverse Mills ratio estimated in a first-stage probit equation in a second-stage profit equation (McBride and Greene, 2009). Mayen, Balagtas, and Alexander (2010) found that if selfselection bias was not corrected for, the TE of organic dairy farms would be underestimated relative to conventional farms. Alternatively, in our SPF approach, we test for selectivity bias in identifying organic versus conventional operators using the approach developed in Greene (2010) for nonlinear SPFs, wherein a significant rho indicates selection bias has been detected and corrected for such that it does not otherwise bias frontier estimation in a statistical sense. Accordingly, and following Nehring, Barton, and Hallahan (2017), we correct for selectivity bias using LIMDEP. The treatment effects test, using a probit model with a dependent variable for organic versus conventional dairies and with independent variables for operator age, operator education, off-farm work hours by the operator and spouse, a household well-being index, an index for urbanization of the area where the farm is located, and total farm acres, resulted in statistically significant drivers and was conclusive with a significant rho. Probit results are included in Appendix Table A1. The interested reader is directed to Greene (2010) for a fuller development of this procedure.

\subsection{Factors Impacting TE}

Impacts of farm and producer characteristics on TE can be measured as "inefficiency effects" on $u_{i t}$. Inefficiency effects are assumed to be independently distributed, and $u_{i t}$ arises by truncation (at zero) of the exponential distribution with mean $\mu_{i t}$ and variance $\sigma^{2}$. The parametric SPF approach, 
introduced by Aigner, Lovell, and Schmidt (1977) and Meeusen and van den Broeck (1977), was modified by Battese and Coelli (1995) to specify stochastic frontiers for TE effects and simultaneously estimate all parameters involved. For the present study, because the treatment effects test conducted in LIMDEP was statistically conclusive, we use LIMDEP to estimate drivers for TE without treatment effect bias in the second-stage estimation procedure rather than follow the model described in Battese and Coelli (1995).

Potential inefficiency drivers included in the model are whether the operator held a 4-year college degree (COLLEGE); the operator's age (AGE); the year the operator began farming (YEAR); whether artificial insemination, embryo transplants, or sexed semen were used to breed dairy cows (AI); whether a dairy parlor was used (PARLOR); the number of hours the operator worked off-farm (PR-OPOFFFARM); the number of hours the spouse worked off-farm (PR-SPOFFFARM); degree of specialization of the farm in dairy production, measured as the value of dairy products divided by the total value of farm production (SPECIALIZE); farm size as measured using two dummy variables, MEDIUM indicating the farm milked 175-749 cows and LARGE indicating the farm milked $\geq 750$ cows, with small farms of $<175$ cows as the base; and regional discrete variables for the HEARTLAND, EAST, and SOUTH, with the combined Mountain States and Pacific regions serving as the base; the level of accessibility to urban areas (URBAN), and index that increases with greater accessibility to urban areas as developed and discussed by Livanis et al. (2006); and a dummy variable for the level of heat and humidity in the farm's location, measured as a temperature-humidity index as used by Key and Sneeringer (2014), assuming levels above the median (HEAT-HUMID).

Greater operator education is expected to lead to higher TE if investment in human capital through education enhances farm decision-making. Qushim et al. (2016) found that operator education was associated with higher TE for meat goat farms. Operator age and experience farming may impact farm efficiency. If older producers are utilizing older technology, they may be less efficient; however, greater experience is likely to positively impact farm efficiency. Featherstone, Langemeier, and Ismet (1997) found operator age to be associated with lower TE for cow-calf farms. The use of specific technologies and production systems may also impact TE. Artificial insemination, embryo transplants, and sexed semen require expertise by the operator or hired labor to implement, but use allows access to superior genetics, may substitute for the use of a bull on the dairy operation, and in the case of sexed semen, allows for a higher percentage of (usually) female births. Use of a dairy parlor represents a different production system than around-the-barn milking. ${ }^{3}$

Operator off-farm hours and spouse off-farm hours may be endogenous to the system, meaning that the independent variable may be correlated with the error term in the regression model. For U.S. dairy operations, off-farm operator and spousal work can provide a significant portion of the farm household income and may impact the farm labor input and/or the efficiency with which inputs are used. Previous research has suggested that off-farm operator labor lowers TE while off-farm spousal labor increases TE (Nehring et al., 2009). We use instrumental variables to predict operator and spousal off-farm labor. The following instruments are used to predict the level of operator and spousal off-farm hours. For operator off-farm hours, the instruments are operator age, operator education, quantity of milk sold, total debt, and acres operated. For spousal off-farm hours, we use spouse age, spouse education, acres operated, the farm debt-to-asset ratio, and total debt. Resulting predicted values of these two variables are included in the inefficiency effects model.

Specialization in the dairy enterprise may positively impact TE if the focus of the operator and labor on one enterprise leads to more efficient use of inputs and the dairy is not technically complementary with other enterprises. Featherstone, Langemeier, and Ismet (1997) found lower TE among more specialized cow-calf farms, while Qushim et al. (2016) found higher TE among more specialized meat goat farms. Farm size may positively impact TE if capital, labor, and management can be more efficiently utilized over greater output. Featherstone, Langemeier, and Ismet (1997),

\footnotetext{
${ }^{3} \mathrm{~A}$ reviewer suggested inclusion of robotics as an additional technology for the analysis. A robotics dummy variable was developed and included in one of the versions of the model, but it was not statistically significant.
} 
Morrison-Paul et al. (2004a), and Samarajeewa, Hailu, and Jeffrey (2012) found higher TE for larger farms. Region may also impact TE due to different production or market conditions. Nehring, Barton, and Hallahan (2017) found higher TE among U.S. dairy farms in areas of higher heat and humidity, and lower TE among dairy farms that were closer to urban areas.

\subsection{Farm Categories and Measures for Comparison}

We compare economic and productivity measures of eight combinations of organic status and farm size in this study. Farms are first divided by organic status, with those farms selling organic milk or transitioning to organic being classified as organic; otherwise they are classified as conventional. Organic farms are further broken into the following size categories: $<75$ cows, $75-174$ cows, and $\geq 175$ cows. Given the greater number of observations for conventional farms, especially for larger dairies, this group is broken into more size categories: $<75$ cows, $75-174$ cows, $175-749$ cows, $750-1,499$ cows, and $\geq 1,500$ cows. These size categories allow for comparisons of farm efficiency measures as estimated from the SPF as well as additional financial, productivity, and economic measures by organic status and farm size. Because ARMS uses a complex sampling procedure and weights to represent the U.S. population of dairy farms, the delete-a-group Jackknife procedure is used in this study for statistical comparisons of means among categories (Dubman, 2000). It is noted that few very large organic dairy farms are included in the dairy ARMS sample. USDANASS's 2016 Certified Organic Dairy Survey reports six organic dairy operations in Texas in 2016 with a total inventory of 27,948 milk cows, for an average of 4,658 cows per farm. This is compared with averages of 473 cows per farm on 106 farms in California, 61 cows per farm on 455 farms in Wisconsin, and 54 cows per farm on 486 farms in New York (USDA-NASS, 2018).

In addition to SPF efficiency measures, production measures that are compared by farm size and system include the number of pasture acres used per cow, pounds of milk produced per cow per year, the use of a dairy parlor, the use of artificial insemination, and the producer keeping individual cow records. Pasture use is measured in the survey as the sum of owned and rented acres used to graze dairy cattle. Because of pasture requirements for organic dairy production, organic farms are expected to have higher pasture use than conventional farms. Furthermore, because of the increased effort and associated higher cost of gathering larger numbers of animals for milking in a pasture-based operation, it is expected that larger farms rely less on pasture than smaller farms. Gillespie et al. (2009) showed that smaller-scale dairy farms were more likely to operate pasture-based dairy farms than larger-scale farms. Milk produced per cow is expected to be higher for conventional than organic, and for larger farms. This is due in part to the greater use of pasture on organic and smaller dairy farms, with pasture-based operations producing on average less milk per cow (Gillespie and Nehring, 2014). Larger-scale dairy operations also tend to be greater adopters of productivity-enhancing technology (Khanal, Gillespie, and MacDonald, 2010), which tends to increase milk produced per cow. We chose dairy parlor, artificial insemination, and individual cow record-keeping to represent production system, technology, and management practices, with all expected to be more heavily adopted by larger-scale producers, as found by Gillespie, Nehring, and Sitienei (2014).

Farm financial measures compared by system and farm size include farm net return on assets, household net return on assets, and farm debt-asset ratio, all of which are whole-farm and not limited to the dairy enterprise. The first two ratios provide measures of farm profitability, the former for the farm business and the latter for the farm household. Net return on assets is defined as net farm income divided by total farm assets. Household net return on assets is defined as (net farm income + total household off-farm income) $\div$ (total household assets). Debt-asset ratio is the total farm debt divided by the total value of farm assets, a measure of the proportion of the value of farm assets that is financed with debt. With economies of size in dairy production, largerscale farms can be expected to have greater net return on assets and household return on assets. 
Different costs and returns for organic versus conventional producers could result in different profitability measures by production system.

Costs and returns for the dairy enterprise are compared among system and size categories using 2016 estimates developed from the 2016 ARMS Phase 3, dairy version. We use the following measures for comparison, as defined in the USDA-ERS Commodity Costs and Returns (2020) and Milk Cost of Production Estimates (2020) for the dairy enterprise on a per-hundredweight of milk produced basis: total gross value of production, purchased feed cost, total feed cost, other operating costs, total operating costs, total allocated overhead, value of production less total operating costs, and value of production less total costs. Total gross value of production includes milk sold, dairy cattle sales, and other dairy income. Total feed costs include purchased feed, the value of homegrown harvested feed used, and the value of grazed feed which is valued as the rental rate for pasture. We report purchased feed costs, with homegrown and grazed feed making up the difference between total feed and purchased feed costs. Other operating cost includes costs for veterinarian and medicine; bedding and litter; marketing; custom services; fuel, lube, and electricity; repairs; interest on operating costs; and for organic farms third-party organic certification costs. Allocated overhead costs include hired labor, opportunity cost of unpaid labor, capital recovery of machinery and equipment, the opportunity cost of land (rental rate), taxes and insurance, and general farm overhead. Total gross value of production is expected to vary by system, with organic farms having higher returns per hundredweight due to the higher price paid for milk. Operating costs are expected to be higher for organic dairies due primarily to the higher cost of organic feeds. Allocated overhead costs are expected to be lower for larger-scale farms due to economies of size.

Cost and return estimates for 2016 U.S. milk using 2016 ARMS data are provided by USDAERS Organic Costs and Returns (2020). The estimates provided in this paper differ from those provided by USDA-ERS Organic Costs and Returns (2020) in the following ways: (1) the size categories differ and (2) statistical differences in costs and returns among size categories and organic/conventional status are provided.

\section{Results}

\subsection{Production and Technology Comparisons by Size Category}

Table 1 presents farm characteristics and economic measures by organic status and farm size. The largest numbers of producers in both organic and conventional size categories were in the smallest size categories for both. The category representing the smallest number of farms is large-scale organic farms with $\geq 175$ cows, representing 443 farms. Conventional farms with $\geq 1,500$ cows produced the most milk, $38.1 \%$ of the total value of production, while organic farms with 75-174 cows produced the least, $1.4 \%$ of the total value of production. The organic and conventional $<75$ cow and 75-174 cow categories had similar numbers of cows per farm by system (averages of 41 versus 49 cows for the smaller size category and 108 versus 114 cows for the larger size category), thus making organic versus conventional comparisons possible within those size categories. The largest size category of farms, conventional with $\geq 1,500$ cows, represented 1,183 farms with an average of 3,722 cows per farm.

Acres of pasture used for grazing dairy cattle decreased for both organic and conventional farms as farm size increased. The highest usage was 0.82 acres/cow for the smallest category of organic farms and the lowest was for conventional $\geq 1,500$ cows, with almost no pasture usage. For all categories, organic dairies used more pasture acreage than conventional dairies, a finding that is consistent with the pasture rules for certified organic milk production. Milk produced per cow generally increased with farm size for both organic and conventional farms, though statistically significant differences were not found among the largest three size categories of conventional dairies. Organic farms produced less milk per cow than conventional farms, which is consistent with the greater use of pasture and lower usage of a total mixed ration (Gillespie and Nehring, 2014). 
Table 1. Characteristics and economic measures of dairy farms by organic status and size, 2016 ARMS dairy survey

\begin{tabular}{|c|c|c|c|c|c|c|c|c|}
\hline Item & $\begin{array}{l}\text { a: Organic } \\
<75 \text { Cows }\end{array}$ & $\begin{array}{c}\text { b: Organic } \\
\text { 75-174 Cows }\end{array}$ & c: Organic $\geq 175$ Cows & $\begin{array}{l}\text { d: Conventional } \\
<75 \text { Cows }\end{array}$ & $\begin{array}{l}\text { e: Conventional } \\
75-174 \text { Cows }\end{array}$ & $\begin{array}{l}\text { f: Conventional } \\
175-749 \text { Cows }\end{array}$ & $\begin{array}{l}\text { g: Conventional } \\
750-1499 \text { Cows }\end{array}$ & $\begin{array}{l}\text { h: Conventional } \\
\quad \geq 1500 \text { Cows }\end{array}$ \\
\hline No. of observations & 276 & 93 & 42 & 227 & 307 & 362 & 109 & 110 \\
\hline No. of farms & 3,804 & 866 & 443 & 16,079 & 7,626 & 5,273 & 1,282 & 1,183 \\
\hline $\begin{array}{l}\% \text { of total farms } \\
\text { represented }\end{array}$ & 10.41 & 2.37 & 1.21 & 43.98 & 20.86 & 14.42 & 3.51 & 3.24 \\
\hline$\%$ total value prod'n represented & 2.03 & 1.38 & 3.18 & 8.17 & 9.44 & 21.98 & 15.71 & 38.11 \\
\hline$\%$ of milk produced & 1.05 & 0.66 & 1.78 & 7.26 & 8.80 & 21.49 & 24.51 & 34.45 \\
\hline Cows per farm & 41 & 108 & 460 & 49 & 114 & 355 & 1,235 & 3,722 \\
\hline Pasture acres/cow & $0.82^{\mathrm{bcdefgh}}$ & $0.65^{\text {abefgh }}$ & $0.46^{\text {aefgh }}$ & $0.31^{\text {abefgh }}$ & $0.15^{\mathrm{abcdgh}}$ & $0.11^{\mathrm{abcdgh}}$ & $0.02^{\text {abcdef }}$ & $0.002^{\mathrm{abcdef}}$ \\
\hline Milk produced/cow/year & $12,975^{\text {cdefgh }}$ & $13,701^{\text {cdefgh }}$ & $16,938^{\text {abefgh }}$ & $17,735^{\text {abefgh }}$ & $19,650^{\text {abcdfgh }}$ & $22,316^{\text {abcde }}$ & $23,347^{\text {abcde }}$ & $22,796^{\text {abcde }}$ \\
\hline Parlor, portion using & $0.30^{\text {bcefgh }}$ & $0.69^{\text {acdfgh }}$ & $0.93^{\text {abde }}$ & $0.29^{\text {bcefgh }}$ & $0.75^{\text {acdfgh }}$ & $0.94^{\text {abdeg }}$ & $0.99^{\text {abdef }}$ & $0.98^{\text {abde }}$ \\
\hline $\begin{array}{l}\text { Art. insemination, } \\
\text { portion using }\end{array}$ & $0.62^{\mathrm{bcdefgh}}$ & $0.83^{\text {ah }}$ & $0.76^{\mathrm{h}}$ & $0.75^{\text {aefgh }}$ & $0.84^{\text {ah }}$ & $0.86^{\mathrm{adh}}$ & $0.84^{\mathrm{adh}}$ & $0.95^{\text {abcdefg }}$ \\
\hline $\begin{array}{l}\text { Indiv. cow records, } \\
\text { portion using }\end{array}$ & $0.56^{\text {cefgh }}$ & $0.66^{\mathrm{cdfgh}}$ & $0.85^{\text {abde }}$ & $0.52^{\text {bcefgh }}$ & $0.70^{\text {acdfgh }}$ & $0.81^{\text {abdegh }}$ & $0.90^{\text {abdef }}$ & $0.93^{\text {abdef }}$ \\
\hline Technical efficiency & 0.927 & $0.922^{\mathrm{efg}}$ & 0.925 & $0.922^{\text {efg }}$ & $0.928^{\mathrm{bd}}$ & $0.928^{\text {bdh }}$ & $0.927^{\mathrm{bd}}$ & $0.924^{f}$ \\
\hline Return to scale & $0.45^{\text {bcdefgh }}$ & $0.60^{\text {acdfgh }}$ & $0.77^{\text {abdefgh }}$ & $0.43^{\text {bcdefgh }}$ & $0.55^{\text {acdfgh }}$ & $0.71^{\text {abcdegh }}$ & $0.88^{\text {abcdefh }}$ & $0.99^{\text {abcdefg }}$ \\
\hline Farm net return on assets & $0.053^{\text {bcde }}$ & $0.092^{\text {adefg }}$ & $0.106^{\text {adefg }}$ & $0.025^{\text {abcefgh }}$ & $0.035^{\mathrm{abcfh}}$ & $0.050^{\text {bcde }}$ & $0.034^{\mathrm{bch}}$ & $0.072^{\text {deg }}$ \\
\hline $\begin{array}{l}\text { Household net return on } \\
\text { assets }\end{array}$ & $0.047^{\mathrm{bcd}}$ & $0.085^{\text {acdefg }}$ & $0.128^{\text {abdefg }}$ & $0.022^{\text {abcefgh }}$ & $0.036^{\mathrm{bcdfgh}}$ & $0.056^{\text {bcde }}$ & $0.045^{\mathrm{bcd}}$ & $0.083^{\mathrm{de}}$ \\
\hline Off-farm income/cow, \$ & $583.13^{\text {bcefgh }}$ & $250.82^{\text {adfgh }}$ & $76.66^{\text {abdegh }}$ & $612.21^{\text {acfgh }}$ & $287.76^{\text {acdfgh }}$ & $105.19^{\text {abdegh }}$ & $26.24^{\text {abcdefh }}$ & $17.52^{\text {abcdefg }}$ \\
\hline College degree, $\%$ of operators & $0.07^{\mathrm{bcfgh}}$ & $0.14^{\text {ade }}$ & $0.24^{\text {abde }}$ & $0.08^{\text {cfgh }}$ & $0.10^{\mathrm{dfgh}}$ & $0.19^{\mathrm{acdh}}$ & $0.22^{\text {adeh }}$ & $0.35^{\text {abdefg }}$ \\
\hline Operator age, years & $47.67^{\text {bcdefgh }}$ & $55.26^{\mathrm{a}}$ & $55.15^{\mathrm{a}}$ & $52.57^{\mathrm{a}}$ & $55.06^{\mathrm{a}}$ & $54.85^{\mathrm{a}}$ & $55.16^{\mathrm{a}}$ & $54.27^{\mathrm{a}}$ \\
\hline $\begin{array}{l}\text { Operator hours off farm, } \\
\text { hours/year }\end{array}$ & $81.32^{\mathrm{eh}}$ & 96.88 & 79.06 & $108.77^{e}$ & $42.36^{\text {adgh }}$ & $82.26^{\mathrm{h}}$ & $136.17^{\mathrm{e}}$ & $221.24^{\text {aef }}$ \\
\hline $\begin{array}{l}\text { Spouse hours off farm, } \\
\text { hours/year }\end{array}$ & $236.04^{\text {cde }}$ & $323.84^{f}$ & 380.84 & $370.75^{\text {af }}$ & $385.40^{\mathrm{a}}$ & $508.20^{\text {abgh }}$ & $301.63^{f}$ & $315.46^{f}$ \\
\hline Debt-asset ratio & $0.220^{\text {cdeh }}$ & $0.161^{\mathrm{dg}}$ & $0.070^{\text {adefgh }}$ & $0.389^{c f g h}$ & $0.152^{\text {acdfg }}$ & $0.201^{\text {cdegh }}$ & $0.404^{\text {bcdefh }}$ & $0.176^{\mathrm{acdfg}}$ \\
\hline
\end{tabular}


Table 1. (Continued)

\begin{tabular}{|c|c|c|c|c|c|c|c|c|}
\hline Item & $\begin{array}{l}\text { a: Organic } \\
<75 \text { Cows }\end{array}$ & $\begin{array}{c}\text { b: Organic } \\
75-174 \text { Cows }\end{array}$ & c: Organic $\geq 175$ Cows & $\begin{array}{l}\text { d: Conventional } \\
<75 \text { Cows }\end{array}$ & $\begin{array}{l}\text { e: Conventional } \\
75-174 \text { Cows }\end{array}$ & $\begin{array}{l}\text { f: Conventional } \\
175-749 \text { Cows }\end{array}$ & $\begin{array}{l}\text { g: Conventional } \\
750-1499 \text { Cows }\end{array}$ & $\begin{array}{l}\text { h: Conventional } \\
\geq 1500 \text { Cows }\end{array}$ \\
\hline Land price, \$/acre & $4,712^{\text {bfgh }}$ & $3,892^{\text {acdefgh }}$ & $5,636^{\mathrm{b}}$ & $4,914^{\mathrm{bgh}}$ & $5,093^{\text {bgh }}$ & $5,507^{\text {abg }}$ & $6,518^{\text {abdef }}$ & $7,308^{\text {abde }}$ \\
\hline Milk price/cwt, \$ & $18.60^{\text {defgh }}$ & $18.41^{\text {defgh }}$ & $21.18^{\text {defgh }}$ & $9.58^{\mathrm{abc}}$ & $9.12^{\mathrm{abc}}$ & $10.49^{\mathrm{abcgh}}$ & $8.82^{\mathrm{abcf}}$ & $7.36^{\mathrm{abc}}$ \\
\hline $\begin{array}{l}\text { Gross value of } \\
\text { production/cwt, \$ }\end{array}$ & $36.32^{\text {bdefgh }}$ & $39.14^{\text {acdefgh }}$ & $34.88^{\text {bdefgh }}$ & $18.79^{\mathrm{abch}}$ & $18.38^{\mathrm{abcfh}}$ & $18.91^{\text {abceh }}$ & $18.32^{\mathrm{abc}}$ & $17.69^{\text {abcdef }}$ \\
\hline $\begin{array}{l}\text { Purchased feed } \\
\text { cost/cwt, \$ }\end{array}$ & $6.65^{\text {defh }}$ & $7.71^{\text {acde }}$ & $8.40^{\text {def }}$ & $4.782^{\mathrm{abcfgh}}$ & $4.75^{\mathrm{abcfgh}}$ & $5.91^{\text {abcdegh }}$ & $7.07^{\text {def }}$ & $7.55^{\text {adef }}$ \\
\hline Total feed cost/cwt, \$ & $16.73^{\text {cdefgh }}$ & $16.20^{\text {defgh }}$ & $13.54^{\text {adefgh }}$ & $9.90^{\mathrm{abcf}}$ & $9.61^{\mathrm{abc}}$ & $8.97^{\mathrm{abcd}}$ & $9.20^{\mathrm{abc}}$ & $9.05^{\mathrm{abc}}$ \\
\hline $\begin{array}{l}\text { Other operating } \\
\text { cost/cwt, \$ }\end{array}$ & $5.04^{\operatorname{defgh}}$ & $5.27^{\text {defgh }}$ & $4.25^{\text {defgh }}$ & $4.09^{\mathrm{abfgh}}$ & $3.87^{\mathrm{abfgh}}$ & $3.36^{\text {abdegh }}$ & $2.73^{\mathrm{abcdefh}}$ & $2.37^{\text {abcdef }}$ \\
\hline $\begin{array}{l}\text { Total operating } \\
\text { cost/cwt, \$ }\end{array}$ & $21.77^{\text {cdefgh }}$ & $21.47^{\text {cdefgh }}$ & $17.79^{\text {abdefgh }}$ & $13.99^{\text {abcfgh }}$ & $13.48^{\mathrm{abcfgh}}$ & $12.33^{\mathrm{abcde}}$ & $11.92^{\mathrm{abcde}}$ & $11.42^{\mathrm{abcde}}$ \\
\hline $\begin{array}{l}\text { Allocated overhead } \\
\text { cost/cwt, \$ }\end{array}$ & $23.61^{\text {bcdefgh }}$ & $15.52^{\text {acefgh }}$ & $11.00^{\text {abdggh }}$ & $15.57^{\text {acefgh }}$ & $11.00^{\text {abdfgh }}$ & $8.17^{\text {abcdegh }}$ & $7.12^{\mathrm{abcdefh}}$ & $5.80^{\text {abcdefg }}$ \\
\hline Total cost/cwt, \$ & $45.38^{\text {bcdefgh }}$ & $36.99^{\text {acdefgh }}$ & $28.79^{\text {abefgh }}$ & $29.57^{\text {abefgh }}$ & $24.48^{\text {abcdfgh }}$ & $20.50^{\text {abcdegh }}$ & $19.04^{\text {abcdefh }}$ & $17.22^{\mathrm{abcdefg}}$ \\
\hline $\begin{array}{l}\text { Value prod. less total } \\
\text { cost/cwt, } \$\end{array}$ & $-9.07^{\text {bcfgh }}$ & $2.16^{\text {acdefg }}$ & $6.08^{\text {abdefgh }}$ & $-10.78^{\text {bcefgh }}$ & $-6.10^{\mathrm{bcdfgh}}$ & $-1.59^{\text {abcdeh }}$ & $-0.72^{\text {abcde }}$ & $0.47^{\text {acdef }}$ \\
\hline $\begin{array}{l}\text { Value prod. less } \\
\text { oper. cost/cwt, \$ }\end{array}$ & $14.55^{\text {bdefgh }}$ & $17.67^{\text {adefgh }}$ & $17.08^{\text {defgh }}$ & $4.79^{\text {abcfgh }}$ & $4.91^{\text {abcfgh }}$ & $6.58^{\text {abcde }}$ & $6.40^{\text {abcde }}$ & $6.27^{\text {abcde }}$ \\
\hline$X_{L A B} /$ cwt milk & $21.77^{\text {bcdefgh }}$ & $9.01^{\text {acdefgh }}$ & $5.12^{\text {abdefgh }}$ & $12.86^{\text {abcefgh }}$ & $6.94^{\mathrm{abcdfgh}}$ & $3.83^{\text {abcdegh }}$ & $2.87^{\mathrm{abcdefh}}$ & $2.20^{\mathrm{abcdefg}}$ \\
\hline$X_{\text {Отн }} / \mathrm{cwt}$ milk & $42.03^{\text {defgh }}$ & $39.97^{\text {defgh }}$ & $40.47^{\text {defgh }}$ & $30.86^{\mathrm{abc}}$ & $29.58^{\mathrm{abc}}$ & $30.51^{\mathrm{abc}}$ & $30.77^{\mathrm{abc}}$ & $31.31^{\mathrm{abc}}$ \\
\hline$X_{M I S C} / \mathrm{cwt}$ milk & $7.13^{\mathrm{bcdefgh}}$ & $7.31^{\text {acdefgh }}$ & $4.41^{\text {abdefgh }}$ & $3.70^{\text {abcefgh }}$ & $3.08^{\mathrm{abcdfgh}}$ & $2.45^{\mathrm{abcegh}}$ & $2.45^{\text {abceg }}$ & $1.39^{\mathrm{abcefg}}$ \\
\hline$X_{\text {LAND }} /$ cwt milk & $23.09^{\text {bcdefgh }}$ & $15.97^{\text {acdefgh }}$ & $9.45^{\text {abdefgh }}$ & $16.86^{\text {abcefgh }}$ & $12.45^{\text {abcegh }}$ & $6.97^{\text {abcegh }}$ & $3.23^{\text {abcefh }}$ & $1.68^{\text {abcefg }}$ \\
\hline
\end{tabular}

Note: Superscripts indicate estimate is statistically significantly different from corresponding values in columns a-h: organic $<75$ cows $=a$, etc.

Source: Model results and USDA data 2002-2016 ARMS. The $t$-statistics are based on weighting techniques described in Dubman. 
Table 2. Input distance function parameter estimates, 2016 dairy

\begin{tabular}{|c|c|c|}
\hline Variable & Parameter Estimate & $t$-test \\
\hline$\alpha_{0}$ & $13.602^{\star \star \star}$ & 22.44 \\
\hline$\alpha_{\mathrm{XLAB}}$ & $-0.576^{\star \star \star}$ & -21.11 \\
\hline$\alpha_{\text {XMISC }}$ & 0.032 & 0.92 \\
\hline$\alpha_{X \mathrm{XAP}}$ & $-0.164^{\star \star \star}$ & -7.49 \\
\hline$\beta_{\text {YOTH }}$ & 0.029 & 0.50 \\
\hline$\beta_{\text {YDAIR }}$ & $-1.114^{\star \star \star}$ & -14.26 \\
\hline$\beta_{\text {YOTH,YOTH }}$ & -0.001 & -0.52 \\
\hline$\beta_{\text {YDAIR,YDAIR }}$ & $0.065^{\star \star *}$ & 23.74 \\
\hline$\beta_{\text {YOTH,YDAIR }}$ & 0.004 & -0.03 \\
\hline$\gamma_{\text {YDAIR,TEXT }}$ & 0.044 & 1.49 \\
\hline$\gamma_{\text {YDAIR, WATHCAP }}$ & $-0.003^{\star \star}$ & -2.52 \\
\hline$\gamma_{\text {YOTH,URBAN }}$ & $0.002^{\star \star \star}$ & 4.83 \\
\hline$\alpha_{\mathrm{XLAB}, \mathrm{XLAB}}$ & $-0.056^{\star \star \star}$ & -7.21 \\
\hline$\alpha_{\mathrm{XMISC}, \mathrm{XMISC}}$ & $-0.099^{\star * \star}$ & -12.07 \\
\hline$\alpha_{X C A P, X C A P}$ & $-0.018^{\star \star \star}$ & -4.55 \\
\hline$\alpha_{X L A B, X M I S C}$ & $0.127^{\star \star \star}$ & 10.09 \\
\hline$\alpha_{X L A B, X C A P}$ & 0.014 & 1.47 \\
\hline$\alpha_{\mathrm{XMISC}, \mathrm{XCAP}}$ & $0.029^{\star \star \star}$ & 3.28 \\
\hline$\alpha_{\text {ORGANIC }}$ & $-0.279^{\star \star \star}$ & -2.98 \\
\hline $\mathrm{Rho}_{(w, v)}$ & $0.450^{\star \star}$ & 2.37 \\
\hline$\delta_{(u)}$ & $0.098^{*}$ & 1.95 \\
\hline$\delta_{(v)}$ & $0.266^{\star \star}$ & 18.59 \\
\hline No. of farms & 36,566 & \\
\hline Obs & 1,526 & \\
\hline Eff & 0.926 & \\
\hline RTS & $0.642^{\star \star \star}$ & \\
\hline
\end{tabular}

Notes: ${ }^{* \star \star}$ significance at the $1 \%$ level $(t=2.977),{ }^{\star \star}$ significance at the $5 \%$ level $(t=2.145)$, and ${ }^{*}$ significance at the $10 \%$ level $(t=1.761)$.

Sources: Analysis of USDA Agricultural Resource Management Survey Data. The $t$-statistics are based on LIMDEP base run weights. Finally, note that significance levels for the marginal contributions and RTS are derived by dividing constructed means/CVs in SAS. Refer to Equations ( $1 \mathrm{a}$ and $1 \mathrm{~b}$ ) in the text for a description of the variable names used in the estimation.

Of the three technologies and management systems chosen for examination (use of a parlor, use of artificial insemination, and use of individual cow records), the largest differences in usage were by farm size, with larger-scale operations in both organic and conventional systems more heavily utilizing all three. Differences were not seen in usage by production system except with artificial insemination. For the smallest ( $<75$ cows) operations, organic producers had a lower level of usage of artificial insemination than conventional producers.

\subsection{Stochastic Frontier Results}

Table 2 shows SPF estimates. Of the 22 model coefficients, 16 are significant at $P \leq 0.10$. The ORGANIC variable is significant and has a negative sign, meaning that the organic system shifts 
Table 3. Marginal productive contributions for outputs and inputs ( $t$-statistics)

\begin{tabular}{|c|c|c|c|c|c|}
\hline $\mathrm{MPC}_{\text {ҮотH }}$ & 0.012 & $(2.12)^{*}$ & $M P C_{X L A B}$ & -0.346 & $(-2.50)^{\star \star}$ \\
\hline$M P C_{Y D A I R}$ & 0.630 & $(3.54)^{\star \star \star \star}$ & $M P C_{X M I S C}$ & -0.363 & $(-2.08)^{\star}$ \\
\hline \multirow[t]{2}{*}{ RTS } & 0.642 & $(3.57)^{\star \star \star}$ & $M P C_{X C A P}$ & -0.074 & $(-1.64)^{*}$ \\
\hline & & & $M P C_{X L A N D}$ & -0.211 & $(-2.65)^{\star \star \star}$ \\
\hline
\end{tabular}

Notes: ${ }^{* \star *}$ significance at the $1 \%$ level $(t=2.977),{ }^{* *}$ significance at the $5 \%$ level $(t=2.145)$, and ${ }^{*}$ significance at the $10 \%$ level $(t=1.761)$. Source: USDA ARMS (2016). Note that significance levels for the marginal contributions and RTS are derived by dividing constructed means/ CVs in SAS. As described in Section 2.1, $Y_{D A I R}=$ value of dairy production and $Y_{O T H}=$ value of production of all other crops and livestock on the farm. $X_{L A B}=$ labor; $X_{C A P}=$ capital; $X_{M I S C}=$ miscellaneous including fuel, fertilizer, and feed, and $X_{L A N D}=$ land. $R T S=$ returns to scale.

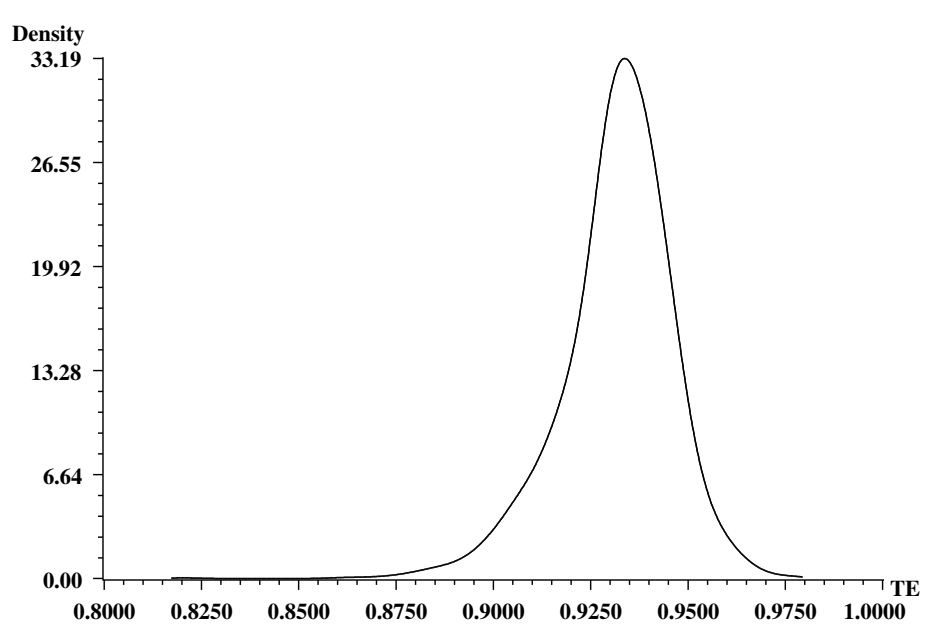

Figure 3. Distribution of technical efficiency estimates from the stochastic production frontier, U.S. Dairy Farms, 2016. Source: LIMDEP results.

the frontier downward. Furthermore, the rho is significant, suggesting there is selection bias associated with opting to operate an organic dairy and is corrected for in our analysis. The productive impacts of both water-holding capacity and population accessibility are statistically significant. That is, higher water-holding capacity appears to increase the productive contribution of (decrease the inputs required for) dairy output, but the reverse is true for population accessibility and its impact on crop and livestock enterprises other than dairy.

The model-based TE estimate is 0.92 at the mean, indicating that the average farm can improve the efficiency of its input usage, see Figure 3 for an illustration of the distribution of TE estimates. On Table 1, we see that organic dairy farms with 75-174 cows were less technically efficient than conventional dairy farms with 75-1,499 cows, conventional farms with 75-1,499 cows were more technically efficient than conventional farms with 74 or fewer farms, and conventional dairy farms with 175-749 cows were more technically efficient than conventional dairy farms with 1,500 or more cows. The lower TE of the largest conventional dairy farms relative to medium-sized 175749 cow conventional farms is consistent with results from Nehring et al. (2016) and Nehring, Barton, and Hallahan (2017) using 2010 ARMS dairy data, where larger-scale operations have not necessarily experienced greater TE. The RTS estimate is 0.64 at the mean, indicating increasing RTS. MPCs for inputs and outputs have the expected signs and all are significant at $P \leq 0.10$ (Table 3). The MPCs for the outputs represent the proportional "marginal cost" or input-use share of the output. By far the largest input share is devoted to dairy. 
Table 4. Technical efficiency drivers

\begin{tabular}{|c|c|c|c|}
\hline Estimate & Coefficient & Standard Error & $t$-test \\
\hline Constant & $0.9775^{\star \star *}$ & 0.0345 & 28.37 \\
\hline College & $0.0038^{\star \star \star}$ & 0.0010 & 3.81 \\
\hline Age & $0.0081^{\star}$ & 0.0046 & 1.75 \\
\hline Year & $-0.0001^{\star \star \star}$ & 0.0005 & -2.60 \\
\hline $\mathrm{Al}$ & $0.0021^{\star}$ & 0.0010 & 2.03 \\
\hline Parlor & $0.0029^{\star \star}$ & 0.0010 & 2.98 \\
\hline Pr-spouse off-farm & 0.0054 & 0.0058 & 0.94 \\
\hline Pr-operator off-farm & $-0.0569^{\star \star}$ & 0.0282 & -2.02 \\
\hline Specialization & $0.0078^{\star \star \star}$ & 0.0020 & 4.00 \\
\hline Medium size & $0.0022^{\star}$ & 0.0013 & 1.65 \\
\hline Large size & 0.0015 & 0.0025 & 0.60 \\
\hline Heartland & -0.0022 & 0.0014 & -1.64 \\
\hline East & $0.0042^{\star \star \star}$ & 0.0016 & 2.65 \\
\hline South & -0.0005 & 0.0023 & -0.20 \\
\hline Temp-humid & $0.0022^{\star \star}$ & 0.0009 & 2.55 \\
\hline Urban & $-0.0143^{\star \star \star *}$ & 0.0026 & -4.52 \\
\hline
\end{tabular}

Notes: ${ }^{* \star *}$ significance at the $1 \%$ level, ${ }^{* *}$ significance at the $5 \%$ level, and ${ }^{*}$ significance at the $10 \%$ level.

Sources: Analysis of USDA Agricultural Resource Management Survey Data. The $t$-statistics are based on LIMDEP base run weights. These variables are described in detail in Section 2.1 of this paper.

Referring back to Table 1, note that for each of the inputs included in the SPF, $X_{C A P}, X_{M I S C}$, $X_{L A B}$, and $X_{L A N D}$, there were significant differences per hundredweight of milk produced by size and system category. Most notably, of the inputs included in the SPF, capital and other inputs (which includes feed) were higher for all organic size classes than for any conventional size class.

Among the TE drivers shown in Table 4, holding a four-year college degree; operator age; year the operator began farming; use of artificial insemination, embryo transplants, or sexed semen; utilizing a milking parlor; operator off-farm work; specialization in dairy; medium size of operation relative to small size; location in the East; relative heat and humidity, and proximity to urban areas are statistically significant at $P \leq 0.10$ or better. Dairy producers holding college degrees operated farms that were more technically efficient than those operated by producers not holding college degrees, consistent with results found by Qushim et al. (2016). Operator age was positively associated with farm TE, and the year the producer began farming was negatively associated with farm TE, both consistent with experience increasing production efficiency.

Farms utilizing advanced breeding technologies (artificial insemination, embryo transfer, or sexed semen) were more technically efficient than those that did not, and farms that utilized a dairy parlor were more technically efficient than those using barn milking systems. Consistent with Nehring et al. (2009), operator off-farm work decreased farm TE. This provides additional evidence of operator off-farm work diverting attention from the farm, reducing TE. Farms more specialized in dairy production were more technically efficient than more diversified farms, suggesting that from a production efficiency perspective, dairy farm specialization is desirable. Medium-sized dairy farms were more technically efficient than small-sized dairy farms. Farms in the Eastern region were more technically efficient than those in the combined Pacific and Western region. Consistent with Nehring, Barton, and Hallahan (2017), dairy farms in areas with greater heat and humidity were more technically efficient than those in areas with lower heat and 


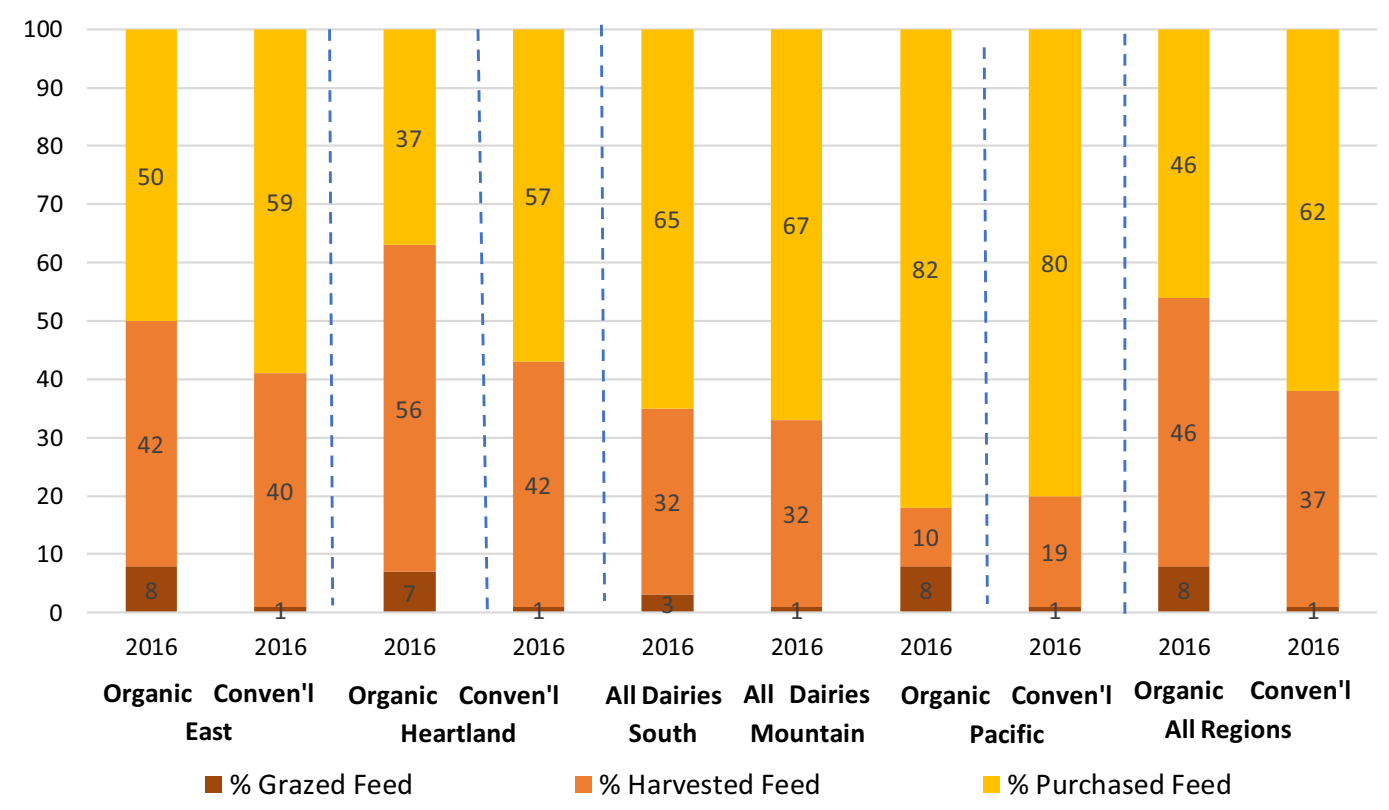

Figure 4. Percent grazing, homegrown, and purchased feed costs by production system and region. Source: 2016 ARMS Phase 3, Dairy Version.

humidity, and dairy farms in closer proximity to urban areas were less technically efficient than those further from urban areas.

Referring back to Table 1 and examining SPF results by system and size, we find that RTS increased with size for both organic and non-organic farms. The smallest farms with $<75$ cows had average RTS measures of 0.47 and 0.45 for organic and conventional, respectively, and the largest conventional farms with $\geq 1,500$ cows had an average RTS $=0.97$. Our largest category of organic farms had an average RTS of 0.78 , but this category was rather wide, including some farms that were medium-sized and some that were very large. Very large organic farms within this category are expected to have RTS $>0.78$. These results show evidence of improved productivity in the use of inputs as farms increase in size, both for organic and conventional farms. Major differences in TE were not found by system and size category, but it is noted that the medium-sized conventional farms had higher TE than some of the other categories, including the largest conventional farms. This is consistent with results of the earlier-reported regression analysis on TE.

\subsection{Comparisons of Dairy Farm Costs and Profitability}

With SPF results clearly showing evidence of economies of size, additional attention to the factors that impact size economies and farm financial measures is warranted. Referring back to Table 1, total feed cost per hundredweight of milk produced did not consistently differ across size categories, but as expected was much lower for conventional than organic farms. Note, however, that the proportions of purchased versus homegrown plus grazed feed changed, with greater proportions of purchased feed for larger-sized conventional farms. Figure 4 provides additional insight on the percentage of feed costs from each of the three feed sources by region, showing that the percentage of feed costs from purchased sources differed by system and region with the West showing notably higher usage of purchased feeds for both systems than other regions. Other operating costs (net feed) were higher for organic than conventional farms, and cost per hundredweight for other 


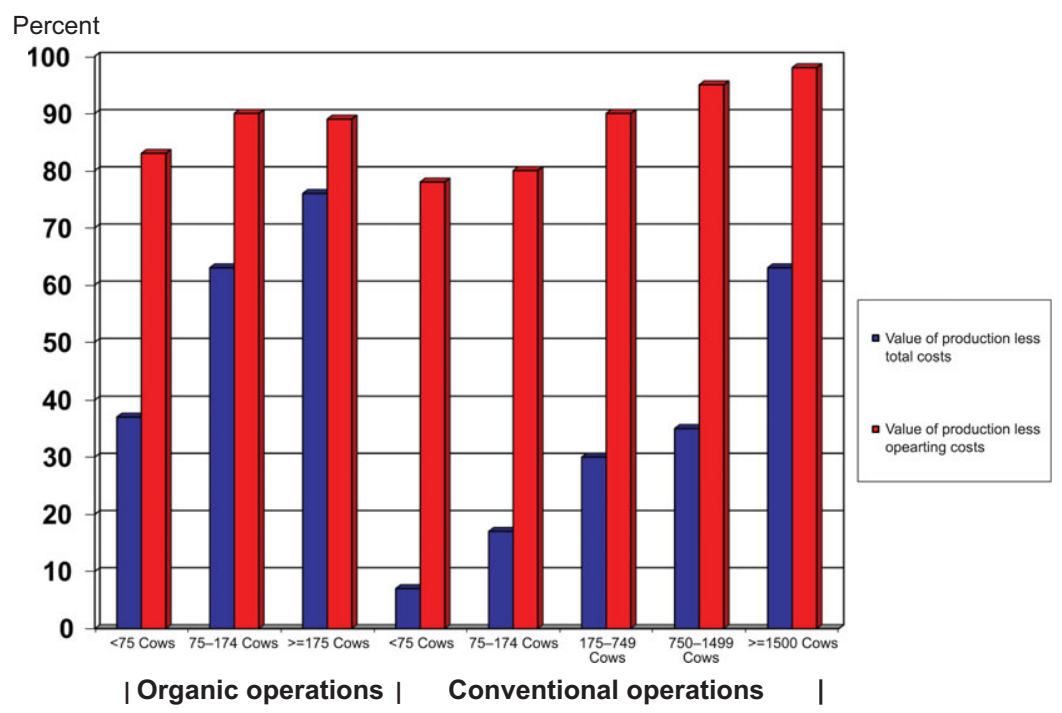

Figure 5. Percentage of U.S. dairy farms with positive profitability measures for the dairy enterprise by class. Some farms are competitive.

operating costs declined with farm size for conventional farms. Total operating costs per hundredweight were higher for organic than conventional producers and declined with larger size for both.

The more notable decreases in costs per hundredweight of milk produced were found with fixed allocated overhead costs. These costs were much higher for organic than conventional farms. Within production systems, the average allocated overhead costs per hundredweight decreased by size category from a high of $\$ 23.61$ to $\$ 11.00$ for organic and from $\$ 15.57$ to $\$ 5.80$ for conventional. Examining dairy commodity cost data from USDA-ERS Organic Costs and Returns (2020) for organic versus conventional dairy farms, all allocated overhead cost components for organic were numerically higher than for conventional dairy farms in 2016. Determination of specific factors that contribute to higher allocated overhead costs among organic dairy farms is a potential area for further research. Average total costs per hundredweight of milk, in turn, also fell strongly with progressively larger size categories, from $\$ 45.38$ to $\$ 28.79$ for organic farms and from $\$ 29.57$ to $\$ 17.22$ for conventional farms.

Factoring in gross value of production per hundredweight, which varied within production system but as expected was much higher for organic than conventional farms, net return over operating cost was higher for organic than conventional farms and higher for the $\geq 175$ cow conventional groups than the $<175$ cow conventional groups. Larger differences were found by size for net return over total cost per hundredweight, progressively increasing from $-\$ 9.07$ to $\$ 6.08$ for organic and from $-\$ 10.78$ to $\$ 0.47$ for conventional farms. The $\geq 75$ cow organic farms experienced higher net return over total costs, on average, than similar-sized conventional farms. Much of the higher return on organic dairy farms is because of the higher milk price received, as shown in Table 1, though costs were also higher.

Though the average farm in some production system/size categories showed negative returns, some farms in all categories showed positive profit. Figure 5 shows the percentages of farms with positive net return over operating costs and net return over total costs. The smallest size categories of both organic and conventional milk production showed negative average net returns over total costs, but substantial portions showed positive net returns over total costs. Likewise, while the largest farms in both production system categories showed positive average net returns over both operating and total costs, some producers in each did not show positive net returns. For 2016, 
for most net return measures and size categories, higher percentages of organic producers than conventional producers of the same size showed positive net returns.

Whole-farm financial measures provide further insight into profitability by system and farm size. Farm net return on assets progressively increased strongly from 0.053 to 0.106 with increasingly larger organic farms, and from 0.025 to 0.072 from the smallest to the largest conventional farms. Household return on assets showed a more dramatic increase among size categories, from 0.047 to 0.128 among the progressively larger organic size categories, and from 0.022 to 0.083 for conventional farms. It is noteworthy that farm and household returns on assets for medium- and large-scale organic farms exceed those of similar-sized conventional farms. Debt-asset ratio showed a significant decline from 0.220 to 0.070 from the smallest to the largest organic size category, but the pattern for conventional farms was less clear. Farms with the lowest debt-asset ratios were those in the $\geq 175$ cow organic category. Land values as reported by respondents to the ARMS generally increased with farm size, with the largest conventional dairies farming the highest-value land. For some farms, higher land values will be reflected in the whole-farm financial measures. ${ }^{4}$

\section{Conclusions}

The U.S. dairy industry consists of a wide range of farm sizes and multiple production systems. Over $50 \%$ of U.S. dairy farms milk fewer than 75 cows but produce less than $10 \%$ of the milk, while less than $4 \%$ milk greater than 1,500 cows but produce more than $40 \%$ of the milk. Two of the most distinct production systems in the dairy industry include organic and conventional production. This level of diversity among farms naturally leads to questions of competitiveness of farms by size and production system. Results of this study highlight differences in production systems used by organic versus conventional producers, as well as producers of different sizes of operation.

Differences in the use of pasture by production system are particularly striking, with organic farms utilizing much greater pasture as expected due to the requirement of pasture use for organic certification. Larger-scale operations under both production systems used less pasture. However, pasture use in the largest organic size categories was still higher than pasture use in the smallest conventional size categories, and the largest conventional operations used virtually no pasture. Of the three chosen technologies, management practices and production systems (parlor, artificial insemination, and individual cow record-keeping), the bigger differences in usage were by farm size (larger farms more likely than smaller farms to adopt) rather than organic/conventional status.

Our estimated SPF included an organic dummy variable and corrected for selection bias associated with organic production, so major differences were not found in TE by organic/ conventional status. Average TE values by system and size category ranged from 0.920 to 0.927, which would not generally be considered a wide range. Nonetheless, a number of TE drivers were found, with medium-sized farms more technically efficient than small farms. Furthermore, older, more experienced, more highly educated farmers who worked fewer hours off-farm and were more specialized in dairy and used advanced breeding technologies and parlor systems were more technically efficient. These results provide additional perspective to the literature on the drivers of TE in farming.

Perhaps the more interesting results from the SPF analysis show RTS associated with dairy farming. RTS for the smallest organic and conventional farms ( $<75$ cows) were 0.46 and 0.47 ,

\footnotetext{
${ }^{4} \mathrm{An}$ area of future research that would be of interest is further examination of farm finances by system and size. Note, for example, that organic dairy farms utilize more pasture than conventional farms, though land values for pasture are generally lower than land values for cropland. A more thorough investigation of the associated impacts on financial measures such as net return on assets, debt-asset ratio, and other measures would provide additional insight on dairy farm financial performance.
} 
respectively, and for the $\geq 1,500$ cow conventional category 0.97 . This provides strong evidence of economies of size up to the largest size category examined in our study. Further evidence of economies of size is seen by examining costs of production. Operating costs per hundredweight, including feed and other costs, declined with farm size, from $\$ 21.77$ for the smallest organic size category to $\$ 17.79$ for the largest organic size category, and $\$ 13.99$ to $\$ 11.42$ for conventional. The more dramatic decline is for allocated overhead costs, which decreased from $\$ 23.61$ to $\$ 11.00$ for organic and $\$ 15.57$ to $\$ 5.80$ for conventional. These cost differences by size provide additional perspective on the continued growth in dairy farm size in the U.S., and the incentive for both organic and conventional dairy farms to expand.

With lower costs per unit produced, larger-scale operations were on average more profitable, as evidenced by whole-farm, household, and enterprise costs and returns. Comparing across production systems for 2016, using whole-farm, household, and enterprise measures of profitability, organic dairies experienced greater profitability than conventional dairies of similar sizes. Though smaller farms on average did not cover total costs of production, some farms were competitive in all size categories.

Given results of this study, it is expected that dairy farm size will continue to increase in order to benefit from economies of size. While there are significant economies to be realized in organic dairy production, pasture requirements may limit many producers' abilities to expand extensively. If one took only the results of this study to be indicative of what can be expected in the future, the conclusion on the basis of returns on assets and dairy enterprise net returns would be that smaller-scale organic dairy farms can be relatively competitive with larger conventional farms. We caution the reader, however, that ERS costs and returns estimates using 2005 and 2010 ARMS data do not indicate profitability differences by production system of the same magnitude as the 2016 results. Thus, we suggest further research on production system competitiveness as new data become available through future ARMS and other surveys.

Acknowledgements. The findings and conclusions in this publication are those of the authors and should not be construed to represent any official USDA or U.S. Government determination or policy.

Financial Support. This research was supported by the intramural research program of the U.S. Department of Agriculture, Economic Research Service.

\section{References}

Aigner, D., C.A.K. Lovell, and P. Schmidt. "Formulation and Estimation of Stochastic Frontier Production Function Models." Journal of Econometrics 6(1977):21-37.

Ball, V.E., W.A. Lindamood, R. Nehring, and C.S.J. Mesonada. "Capital as a Factor of Production in OECD Agriculture: Measurement and Data." Applied Economics 40(2008):1253-1277.

Battese, G.E., and T.J. Coelli. "A Model for Technical Inefficiency Effects in a Stochastic Frontier Production Function for Panel Data.” Empirical Economics 20,2(1995):325-332.

Butler, L.J. "The Economics of Organic Milk Production in California: A Comparison with Intensive Costs." American Journal of Alternative Agriculture 17(2002):83-91.

Dalton, T.J., L.A. Bragg, R. Kersbergen, R. Parsons, G. Rogers, D. Kauppila, and Q. Wang. "Costs and Returns to Organic Dairy Farming in Maine and Vermont for 2004.” Staff Paper 555. Orono, Maine: Department of Resource Economics, University of Maine, 2005.

Dubman, R.W. "Variance Estimation with USDA's Farm Costs and Returns Surveys and Agricultural Resource Management Study Surveys." Staff Paper AGES 00-01, Washington DC: USDA Economic Research Service, 2000.

Econometric Software, Inc. LIMDEP, Version 8.0. Plainview, NY: Econometric Software, 2003.

Fare, R., and D. Primont. Multi-output Production and Duality: Theory and Applications. Boston: Kluwer Academic Publishers, 1995.

Featherstone, A., M. Langemeier, and M. Ismet. “A Nonparametric Analysis of Efficiency for a Sample of Kansas Beef Cow Farms.” Journal of Agricultural and Applied Economics 29,1(1997):175-184.

Gillespie, J., and R. Nehring. "Pasture-based Versus Conventional Milk Production: Where Is the Profit?" Journal of Agricultural and Applied Economics 46,4(2014):543-558. 
Gillespie, J., R. Nehring, and I. Sitienei. "The Adoption of Technologies, Management Practices, and Production Systems in U.S. Milk Production." Agricultural and Food Economics 17(2014):420.

Gillespie, J., R. Nehring, C. Hallahan, and C. Sandretto. "Pasture-Based Dairy Systems: Who Are the Producers and Are Their Operations More Profitable than Conventional Dairies?" Journal of Agricultural and Resource Economics 34,3(2009):412-427.

Greene, C. "U.S. Organic Farming Emerges in the 1990s: Adoption of Certified Systems." Washington, DC: AIB-770, USDAEconomic Research Service, 2001.

Greene, C., G. Ferreira, A. Carlson, B. Cooke, and C. Hitaj. "Growing Organic Demand Provides High-Value Opportunities for Many Types of Producers.” Washington, DC: Amber Waves, USDA-Economic Research Service, 2017.

Greene, C., and A. Kremen. "U.S. Organic Farming in 2000-2001: Adoption of Certified Organic Systems." Washington, DC: AIB 780, USDA-Economic Research Service, 2003.

Greene, C. and W. McBride. "Consumer Demand for Organic Milk Continues to Expand-Can the U.S. Dairy Sector Catch Up?" Choices 30,1(2015):1-6.

Greene, W.H. “A Stochastic Frontier Model with Correction for Sample Selection." Journal of Productivity Analysis 34,1(2010):15-24.

Hanson, J., R. Dismukes, W. Chambers, C. Greene, and A. Kremen. "Risk and Risk Management in Organic Agriculture: Views of Organic Farmers." Renewable Agriculture and Food Systems 19,4(2004):218-227.

Key, N., and S. Sneeringer. "Potential Effects of Climate Change on the Productivity of U.S. Dairies." American Journal of Agricultural Economics 96,4(2014):1136-1156.

Khanal, A., J. Gillespie, and J. MacDonald. “Adoption of Technology, Management Practices, and Production Systems in US Milk Production.” Journal of Dairy Science 93,12(2010):6012-6022.

Livanis, G., C.B. Moss, V.E. Breneman, and R.F. Nehring. "Urban Sprawl and Farmland Prices." American Journal of Agricultural Economics 88,4(2006):915-929.

Lovell, C.A.K., S. Richardson, P. Travers, and L.L. Wood. "Resources and Functionings: A New View of Inequality in Australia." Models and Measurement of Welfare and Inequality. W. Eichhorn, ed. Berlin: Springer-Verlag Press, 1994.

Mayen, C.D., J.V. Balagtas, and C.E. Alexander. "Technology Adoption and Technical Efficiency: Organic and Conventional Dairy Farms in the United States." American Journal of Agricultural Economics 92,1(2010):181-195.

Mayen, C.D., J.V. Balagtas, and C.E. Alexander. "Vertical Economies of Scope in Dairy Farming." Journal of Agricultural and Food Industrial Organization 7,1(2009):1-15.

McBride, W.D., and C. Greene. "Costs of Organic Milk Production on U.S. Dairy Farms.” Review of Agricultural Economics 31,4(2009):793-813.

Meeusen, W., and J. van den Broeck. "Efficiency Estimation from Cobb-Douglas Production Functions with Composed Error. International Economic Review 18,2(1977):435-444.

Morrison-Paul, C., R. Nehring, D. Banker, and A. Somwaru. "Scale Economies and Efficiency in U.S. Agriculture: Are Traditional Farms History?” Journal of Productivity Analysis 22(2004a):185-205.

Morrison-Paul, C., R. Nehring, and D. Banker. "Productivity, Economies, and Efficiency in U.S. Agriculture: A Look at Contracts.” American Journal of Agricultural Economics 86(2004b):1308-1314.

Nehring, R.F., R. Barton, and C. Hallahan. "The Economics and Productivity of US Dairy Farms that Use Crossbred Versus Non-Crossbred Breeding Technology (Production Systems).” Agricultural Finance Review 77,2(2017):275-294.

Nehring R, C. Barnard, D. Banker, and V. Breneman. "Urban Influence on Costs of Production in the Corn Belt." American Journal of Agricultural Economics 88,4(2006):930-946.

Nehring, R., K. Erickson, J.M. Harris, C. Hallahan, A. Katchova, and F. Badau. "Impacts of Urbanization on Costs of Production and Land Use in the Central Southern Seaboard: A Farm-Level Analysis." Journal of Applied Farm Economics 2,3(2018):37-54.

Nehring, R., J. Gillespie, C. Sandretto, and C. Hallahan. "Small U.S. Dairy Farms: Can They Compete?" Agricultural Economics 40(2009):817-825.

Nehring, R., J. Sauer, J. Gillespie, and C. Hallahan. "United States and European Union Dairy Farms: Where Is the Competitive Edge?” International Food and Agribusiness Management Review 19B(2016):219-240.

Qushim, B., J. Gillespie, K. McMillin, and K. Paudel. "Technical and Scale Efficiencies of Meat Goat Farms in the USA." Applied Economics 48,7(2016):608-620.

Reksen, O., A. Tverdal, and E. Ropstad. "A Comparative Study of Reproductive Performance in Organic and Intensive Dairy Husbandry." Journal of Dairy Science 88,7(2005):2462-2475.

Rosati, A., and A. Aumaitre. "Organic Dairy Farming in Europe" Livestock Production Science 90(2004):42-51.

Samarajeewa, S., G. Hailu, and S.R. Jeffrey. "Analysis of Production Efficiency of Beef Cow-Calf Farms in Alberta". Applied Economics" 44,3(2012):313-322.

St. Piere, N.R., B. Cobanov, and G. Schnitkey. "Economic Loss from Heat Stress by U.S. Livestock Industries." Journal of Dairy Science 86,E Suppl.(2003):E52-E77.

U.S. Department of Agriculture, Economic Research Service. Commodity Costs and Returns Data Product, 2020. Internet site: https://www.ers.usda.gov/data-products/commodity-costs-and-returns/ (Accessed November 10, 2020). 
U.S. Department of Agriculture, Economic Research Service. Milk Cost of Production Estimates, 2020. Internet site: https://www.ers.usda.gov/data-products/milk-cost-of-production-estimates/ (Accessed November 10, 2020).

U.S. Department of Agriculture, Economic Research Service. Organic Costs and Returns, 2020. Internet site: https://www. ers.usda.gov/data-products/commodity-costs-and-returns/organic-costs-and-returns/ (Accessed November 10, 2020).

U.S. Department of Agriculture, National Agricultural Statistics Service. 2016 Certified Organic Survey State Publications, 2018. Internet site: https://www.nass.usda.gov/Surveys/Guide_to_NASS_Surveys/Organic_Production/2016_State_ Publications/index.php (Accessed October 25, 2019).

Willer, H., and J. Lernoud, eds. The World of Organic Agriculture. Statistics and Emerging Trends. Nurnberg, Germany; Bonn: Research Institute of Organic Agriculture (FiBL); Frick, and IFOAM-Organics International, 2019.

Zwald, A.G., P.L. Ruegg, J.B. Kaneene, L.D. Warnick, S.J. Wells, C. Fossler, and L.W. Halbert. "Management Practices and Reported Antimicrobial Usage on Intensive and Organic Dairy Farms.” Journal of Dairy Science 87(2004):191-201.

\section{Appendix}

Table A1. Results of the probit model used to develop the selectivity adjustment in the stochastic production frontier, dependent variable organic versus conventional dairy production

\begin{tabular}{lccc}
\hline Estimate & Coefficient & Standard Error & $t$-test \\
\hline Constant & $66.0892^{\star \star \star}$ & 10.7314 & 6.16 \\
\hline Age & $0.0445^{\star \star \star}$ & 0.0104 & 4.29 \\
\hline Education & $-0.2702^{\star \star \star}$ & 0.0689 & -3.92 \\
\hline Pr-operator off-farm & $-54.9237^{\star \star *}$ & 9.1115 & -6.03 \\
\hline Pr-spouse off-farm & $-2.7573^{\star \star *}$ & 0.7769 & -3.55 \\
\hline Household wellbeing & $0.2165^{\star \star *}$ & 0.0440 & 4.92 \\
\hline Urban & $-1.1095^{\star *}$ & 0.2854 & -3.89 \\
\hline Acres & $228.4040^{*}$ & 127.1627 & 1.80 \\
\hline
\end{tabular}

Notes: ${ }^{* \star *}$ significance at the $1 \%$ level, ${ }^{\star *}$ significance at the $5 \%$ level, and ${ }^{*}$ significance at the $10 \%$ level.

Sources: Analysis of USDA Agricultural Resource Management Survey Data. The $t$-statistics are based on LIMDEP base run weights.

Cite this article: Nehring RF, Gillespie J, Greene C, and Law J (2021). The Economics and Productivity of Organic versus Conventional U.S. Dairy Farms. Journal of Agricultural and Applied Economics 53, 134-152. https://doi.org/10.1017/ aae.2020.34 